and mineral composition are similar to other members of the group.A. F. Hallimond: On Autunite. It is concluded that the Cornish material is essentially different from the Autun mineral, and the name bassetite is proposed for the former, the fundamental characters of which are: oblique, $\beta=89^{\circ} 17^{\prime}, a: b: c=0.3473: 1: 0.3456$; forms $010,110,120,011,111,121, \overline{1} 21,141, \overline{1} 01$; twinning by parallel growth of $a$ and $c$ axes, perfect cleavage parallel to 010 , also 100, 001 ; yellow, transparent; biaxial, $2 \mathrm{E}=110^{\circ}$; pleochroic, pale to deep sellow; soluble in acids.

\title{
OORFASPOINIFINOF.
}

\section{THE UNDERGROUND FLOW OF THE YORKSHIRE DEE IN DENTDALE.}

Sir,-On walking from Hawes Junction to Sedbergh on June 23 this year, after a prolonged period of drought, I found the bed of the Dee quite dry for many hundreds of yards. The river flows over the Great Scar Limestone, and its bed forms an interesting study. Over long stretches the bare limestone was exposed, worn to a slippery smoothness and deroid of any surface pebbles or boulders, except in the numerous cylindrical pot-holes drilled by them, some of which were as much as 10 feet in diameter. Miniature cañons have been cut through the limestone, and, as Dr. Strahan" remarks, "the gradient of the river-bed frequently agrees with the inclination of the strata, and in such cases the water slides for many yards over the smooth surface of the same bedding plane." At intervals waterfalls occur and the river plunges from a stratigraphically higher to a lower limestone bed. This applies more particularly to the river course between the mouth of Cowgill Beck and the seventh milestone from Sedbergh. On the other hand, long stretches occur where the solid rock of the river-bed is completely hidden under a chaos of boulders or shingle. At several points pools of water occurred owing to inflow of tributary streams or springs. These pools were in some cases without visible outlet. Where boulders filled the stream bed immediately below the pool it is, of course, possible that the overflow of the pool took place over the solid rock but beneath the boulders. In other cases the only outlet for the pools must be subterranean. At one place higher up stream than the serenth milestone an inflow of several gallons per minute joined the Dee on its left bank, gushing out from a subterranean channel. ${ }^{2}$ Whether this water was the same as that which disappeared higher up stream or not would be difficult to ascertain without chemical tests. It seems, however, clear that some of the water of the Dee follows a subterranean course, though it does not necessarily follow that it rejoins the river lower down. The underground course of the Dale Beck near Ingleborough is well known, but, so far as I know, that of the Dee has not been previously mentioned.

\section{B. Hobson.}

${ }^{1}$ Geology of Country around Ingleborough (Nem. Geol. Surv.), 1890, p. 42.

2 I have since seen an underground inflow on the right bank above Lea Yeat. 